\title{
Reproductive biology of Chromidotilapia guntheri (Sauvage, 1882) (Cichlidae, Perciformes) in four coastal rivers (Ehania, Noé, Soumié and Eholié) of Côte d'Ivoire in West Africa
}

\author{
C.K. Boussou(1), Edia O. Edia ${ }^{(1)}$, Felix K. Konan ${ }^{(1)}$, Mamadou Ouattara ${ }^{(1)}$, \\ Allassane Ouattara $^{(1)}$, Germain Gourène ${ }^{(1)}$
}

Received January 7, 2010 / Reçu le 7 janvier 2010

Revised March 26, 2010 / Révisé le 26 mars 2010

Accepted March 29, 2010 / Accepté le 29 mars 2010

Key-words: spawning activities, Chromidotilapia guntheri, streams Ivorian coastal

\section{ABSTRACT}

The reproductive activities of a small Cichlid Chromidotilapia guntheri were investigated from July 2003 to March 2005 in four coastal rivers (Ehania, Eholié, Noé and Soumié), in the southeast of Côte d'Ivoire. Trends in gonadosomatic indices and reproductive stages of development suggested that $C$. guntheri is a multiple (fractional) spawner and breeds all year round with little fluctuation in spawning intensity. However, spawning activities were more intensive in August and September. The estimated mean standard length at first maturity did not differ significantly between rivers. It was, in the overall population, $85.53 \mathrm{~mm} \mathrm{SL}$ for males and $100.13 \mathrm{~mm} \mathrm{SL}$ for females. In general, the sex ratio differed from 1:1 with the predominance of the males in rivers, standard length classes, seasons and the entire population. Absolute fecundity $(F)$ varied from a minimum of 70 to a maximum of 470 eggs. The range of variation in the relative fecundity was from 3066 to 9135 eggs per kilogram of fish in the total population. Fecundity did not differ extensively between rivers. The absolute fecundity relations to fish standard length (SL) and eviscerated weight (We) were best described in the whole population by the following equations: $\mathrm{F}=0.00069 \times \mathrm{SL}^{2.72}$ and $\mathrm{F}=2.54 \times \mathrm{We}^{1.15}$, respectively. Moreover, there was no relationship between absolute fecundity and oocyte diameter.

\section{RÉSUMÉ}

Mots-clés : activités de reproduction, Chromidotilapia guntheri, rivières côtières de Côte d'Ivoire
Les activités de reproduction d'un petit cichlidé, Chromidotilapia guntheri, ont été étudiées de juillet 2004 à mars 2005 dans quatre rivières côtières du sud-est de la Côte d'Ivoire. Le rapport gonadosomatique et les stades de maturité sexuelle ont indiqué que $C$. guntheri effectue des pontes fractionnées et se reproduit toute l'année avec une légère fluctuation dans l'intensité de la reproduction. Cependant, les activités de fraie sont plus intensives aux mois d'août et de septembre. Les tailles de première maturité estimées n'étaient pas significativement différentes d'une rivière à l'autre. Dans toute la population, cette taille était de $85,53 \mathrm{~mm}$ chez les mâles et de 100,13 mm chez les femelles. Le sexe ratio était en général différent de 1:1 avec une prédominance des mâles dans les rivières, les classes de taille, les saisons et dans la population toute entière. La fécondité absolue

(1) Laboratoire d'Environnement et de Biologie Aquatique, Université d'Abobo-Adjamé, 02 BP 801 Abidjan 02 , Côte d'Ivoire, bkofficharles@live.fr 
a varié de 70 à 470 ovocytes dans toute la population et n'a présenté aucune différence significative entre les rivières. Les relations fécondité absolue (F)longueur standard (LS) et fécondité absolue-poids éviscéré (We) ont été mieux décrites respectivement par les équations suivantes : $F=0,00069 \times L^{2,72}$ et $\mathrm{F}=2,54 \times \mathrm{We}^{1,15}$. En outre, il n'est apparu aucune relation entre la fécondité absolue et les diamètres ovocytaires.

\section{INTRODUCTION}

Life-history characteristics can be considered as adaptive because the fitness of an individual organism depends strongly on traits such as fecundity, age at first maturity and longevity. Natural selection does not act on each life-history trait in isolation, but on the combined traits of the whole genotype (Dobzhansky, 1956). An understanding of the reproductive mechanism and breeding patterns of fishes is a basic requirement for the successful management and maximum utilization of fishery resources. Some quantitative aspects of the population structure such as sex ratio, weight-length relationship, condition factor and reproduction are useful tools in fish studies. They reveal either the biological attributes (weight, length and gonadal maturity) or the species relationship to the environmental conditions (Wootton, 1999). Chromidotilapia guntheri is a freshwater cichlid widely distributed in West Africa. It is known from the coastal basins from the River St. John in Liberia to the Cross (Nigeria/Cameroon) (Paugy et al., 2003). C. guntheri exists in the Niger Basin (Benue included). Despite its widespread occurrence, C. guntheri has never been adequately studied. Studies on this species are scarce and available information is on the species distribution in natural habitats (Teugels et al., 1988; Lévêque et al., 1991; Vivien, 1991; Paugy et al., 1994; Konan et al., 2006). Although it is not an economically important species, it does form an important component of the subsistence catch in Ivorian coastal rivers (Gourène et al., 1999; Da Costa et al., 2000; Konan et al., 2006). It is therefore important to know its reproductive biology and spawning behavior so as to ensure its conservation as well as its full utilization as a sustainable resource. This information is also essential for determining the ecological role of this species in these ecosystems (Merron et al., 1990). The present study aimed to determine the reproduction strategy of $C$. guntheri from four coastal rivers in the southeast of Côte d'Ivoire, as an attempt to fill a gap in the knowledge on this fish.

\section{MATERIAL AND METHODS}

\section{> STUDY AREA AND SAMPLING SITES}

The four small coastal rivers (Soumié, Eholié, Ehania and Noé) studied belong to the Western Guinean ichthyoregion, sector Eburnéo-Ghanaian, and are located in lowland rainforest (Daget and Iltis, 1965). Noé River $\left(05^{\circ} 19^{\prime}-05^{\circ} 35^{\prime} \mathrm{N}\right.$ and $02^{\circ} 55^{\prime}-02^{\circ} 47^{\prime} \mathrm{W}$ ) and Ehania River $\left(05^{\circ} 17^{\prime}-05^{\circ} 43^{\prime} \mathrm{N}\right.$ and $02^{\circ} 46^{\prime}-03^{\circ} 03^{\prime} \mathrm{W}$ ) are tributaries of Tanoé River. The Soumié River $\left(05^{\circ} 23^{\prime}-05^{\circ} 39^{\prime} \mathrm{N}\right.$ and $03^{\circ} 15^{\prime}-03^{\circ} 29^{\prime} \mathrm{W}$ ) is a tributary of the Bia River. Eholié River $\left(05^{\circ} 21^{\prime}-05^{\circ} 36^{\prime} \mathrm{N}\right.$ and $\left.03^{\circ} 10^{\prime}-02^{\circ} 59^{\prime} \mathrm{W}\right)$ runs into Aby lagoon (Figure 1) (Konan et al., 2006). In each river, two sampling sites were retained: upstream and downstream.

These rivers were under a multidisciplinary study because they play an important role for human populations in the southeast of Côte d'Ivoire. They are used for domestic activities, agriculture and fisheries and have not yet been subject to ecological studies. 


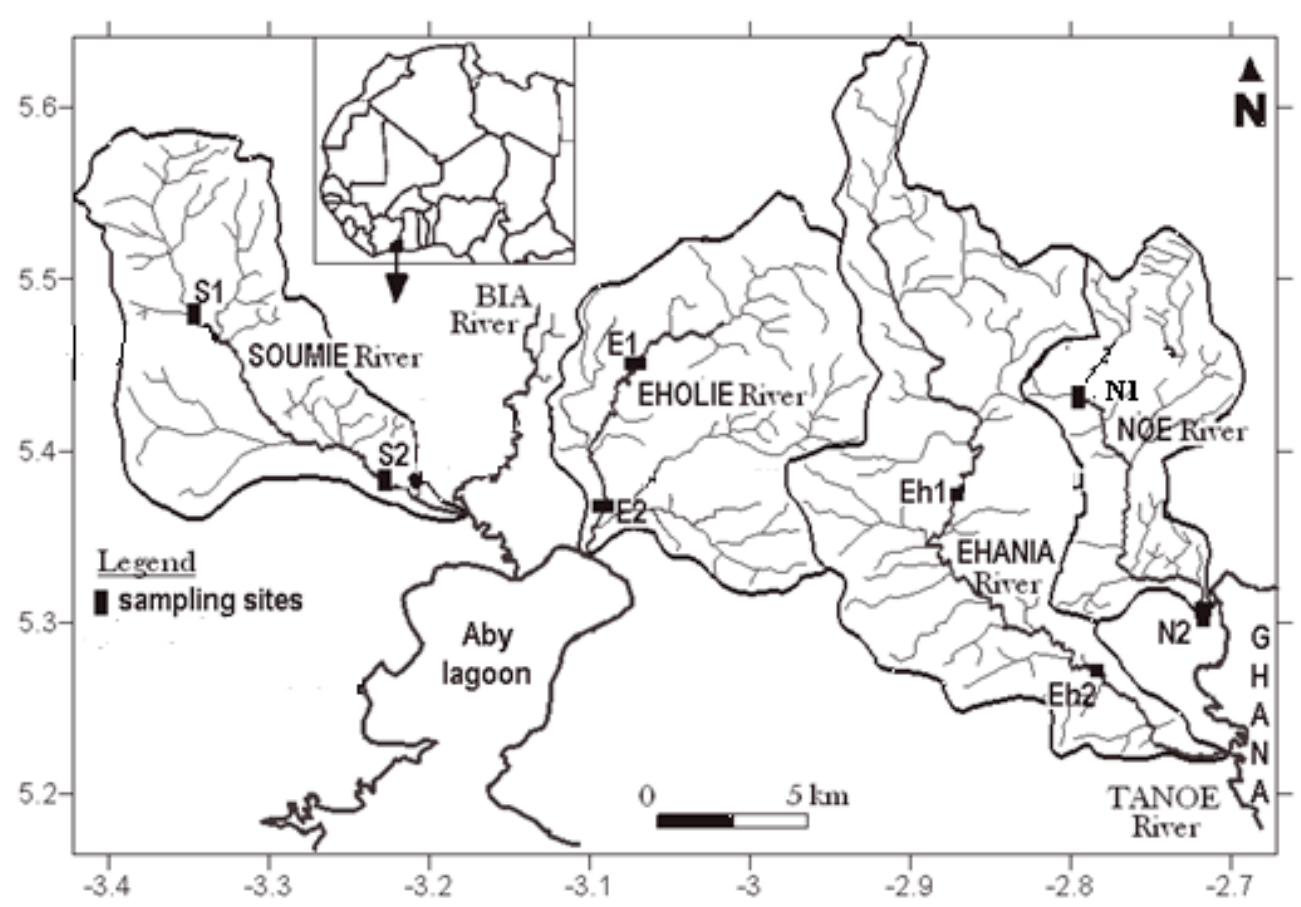

Figure 1

Map of sampling locations. Soumié River, Eholié River, Ehania River, Noé River (Konan et al., 2006). 1 = first sampling site, 2 = second sampling site.

\section{Figure 1}

Carte des sites d'échantillonnage. Rivière Soumié, rivière Eholié, rivière Ehania, rivière Noé (Konan et al., 2006). 1 = première station d'échantillonnage, 2 = deuxième station d'échantillonnage.

\section{Fish sampling}

Fishes were sampled during eight sampling surveys from July 2003 to March 2005. Four surveys were conducted during each season (dry and rainy). The dry season extends from December to March and from August to September, respectively, for the long dry season (LDS) and short dry season (SDS). On the other hand, the rainy season covers from April to July for the long rainy season (LRS) and October to November for the short rainy season (SRS). The eight sites were sampled during each survey. The sampling sites covered a river section of approximately $1.5 \mathrm{~km}$ in length (i.e. reach scale), in order to sample a sufficient degree of habitat heterogeneity. Fishes were collected with two sets of eight gillnets (mesh sizes $12,15,17,22,25,30,40$ and $45 \mathrm{~mm}$ ). Fish specimens were identified according to the identification keys of Paugy et al. (2003). Each specimen was measured (standard length and total length) to the nearest millimeter and weighed to the nearest gram in situ. The mass of ovary and eviscerated fish were recorded and each tissue was then preserved in formalin $10 \%$ for later laboratory observations. The sex of each specimen was determined by examination of the gonad tissue either by eye for large fish or with a lens $(\times 16)$ for smaller fish.

\section{> REPRODUCTIVE PARAMETERS}

The gonadosomatic index (GSI), calculated to assess the reproductive status of fish, was obtained according to Peixer et al. (2006) by the formula:

$$
\mathrm{GSI} \%=\frac{\mathrm{Wg}}{\mathrm{We}} \times 100
$$


where $\mathrm{Wg}$ is the gonad weight, and We the eviscerated weight. The seasonal variation in the GSI was assessed using the Kruskal-Wallis test.

The length at which $50 \%$ of the fish were mature (stages III, IV and V) was regarded as the size at first maturity (L50). It was calculated by fitting a logistic function to the proportion of sexually mature individuals by class size as follows:

$$
p=1 /\left[1+e^{-r(S L-L 50)}\right]
$$

where $p$ is the proportion of mature fish, SL is the standard length (median value of each class size) and $r$ the slope (Tarkan, 2006). The model predicted the proportion of mature fish using nonlinear regression with individuals classed into 10-mm SL intervals. Median values of size classes and corresponding mature fish proportions were used for estimating the function's parameters. The nonlinear regression model performed was the user-specified regression and least squares procedure of Levenberg-Marquardt. When data were not suitable (high redundancy) for this procedure, the user-specified regression and loss function of the quasi-Newton method was executed. Nevertheless, when the number of specimens is insufficient, the smallest mature specimen estimates the size at first maturity (Paugy, 2002). Because males and females sometimes have a different growth pattern, we considered each sex separately. Size at first maturity was compared between rivers and sexes using a $\chi^{2}$ test. Absolute fecundity $(F)$ was estimated by weighing all the eggs in an ovary and counting three subsamples of $1 \mathrm{~g}$ of eggs from different parts of the ovary. The average number of eggs per gram was calculated and multiplied by the total weight of each ovary, giving the total number of eggs per ovary (Dadebo et al., 2003). For the smallest ovaries, complete counts of oocytes were made. Relative fecundity is defined as the number of eggs per kilogram of fish. It was calculated for each female by the quotient of absolute fecundity per the somatic weight. Absolute fecundity and relative fecundity were compared between rivers by the Kruskal-Wallis test.

Samples of 20-30 eggs from each female were collected to measure the egg diameter. Eggs from the anterior, middle and posterior parts of ovaries were measured under a stereomicroscope with an ocular micrometer. Oocyte diameters were compared between rivers using the Kruskal-Wallis test.

The relationship between absolute fecundity and some morphometric measurements was determined by relating absolute fecundity $(F)$ to standard length (SL), eviscerated or somatic weight $(\mathrm{We})$ and oocyte diameter (OD) using the following formula:

$$
\mathrm{F}=\mathrm{a} \times S L^{\mathrm{b}} ; \mathrm{F}=\mathrm{a} \times W \mathrm{e}^{\mathrm{b}} ; \mathrm{F}=\mathrm{a} \times O D^{\mathrm{b}}
$$

where $a$ and $b$ are parameters of fitted lines (Dadebo et al., 2003), and b is a regression coefficient.

These models were performed with the curve fit procedure of Levenberg Marquardt with the software STATISTICA 7.1 (StatSoft, 2005).

The spawning period was established by plotting the fish maturity stage and gonadosomatic index against seasons.

The population sexual structure was examined using $\chi^{2}$ goodness of fit tests to determine whether sex ratios differed significantly $(P<0.05)$ from unity (1:1) (Sadeghi et al., 2009).

\section{RESULTS}

\section{> SEX RATIO}

A total of 212 fishes were collected during the sampling periods. Of these, 23 were unsexed (mostly immature), 114 were males and 75 were females. Thus, the sexual composition 


\section{Table I}

Number of males, females and the corresponding sex ratios by river, season and length class of Chromidotilapia guntheri from four coastal rivers of Côte d'lvoire. LDS = long dry season, LRS = long rainy season, $\mathrm{SDS}=$ short dry season, $\mathrm{SRS}=$ short rainy season, $\mathrm{M}=$ Male, $\mathrm{F}=$ Female.

\section{Tableau I}

Nombre de mâles, de femelles et sexes ratio correspondants selon les rivières, les saisons et les classes de taille de Chromidotilapia guntheri de quatre rivières côtières de Côte d'Ivoire. LDS = grande saison sèche, LRS = grande saison des pluies, SDS = petite saison sèche, SRS = petite saison des pluies, $\mathrm{M}=$ Mâle, $\mathrm{F}=$ Femelle.

\begin{tabular}{lccccc}
\hline Rivers & & Males & Females & Sex ratio (M:F) & $\chi^{2}$ \\
& Eholié & 23 & 9 & $1: 0.39$ & $6.12^{1}$ \\
& Soumié & 22 & 22 & $1: 1.0$ & 0.00 \\
& Ehania & 22 & 27 & $1: 1.23$ & 0.51 \\
& Noé & 47 & 17 & $1: 0.36$ & $14.06^{1}$ \\
& Total & 114 & 75 & $1: 0.66$ & $8.04^{1}$ \\
\hline Seasons & & & & & \\
\hline LDS & 48 & 40 & $1: 0.83$ & 0.73 \\
& LRS & 26 & 9 & $1: 0.35$ & $8.25^{1}$ \\
& SDS & 19 & 7 & $1: 0.37$ & $5.53^{1}$ \\
& SRS & 21 & 19 & $1: 0.9$ & 0.10 \\
& Total & 114 & 75 & $1: 0.66$ & $8.04^{1}$ \\
\hline Length class $^{2}$ & & & & & \\
& $60 ; 70$ & 9 & 5 & $1: 0.56$ & 1.14 \\
& $70 ; 80$ & 12 & 4 & $1: 0.33$ & $4^{1}$ \\
& $80 ; 90$ & 8 & 2 & $1: 0.25$ & 3.60 \\
& $90 ; 100$ & 19 & 14 & $1: 0.78$ & 0.76 \\
& $100 ; 110$ & 20 & 11 & $1: 0.55$ & 2.61 \\
& $110 ; 120$ & 26 & 21 & $1: 0.81$ & 0.53 \\
$120 ; 130$ & 14 & 10 & $1: 0.74$ & 0.67 \\
& $130 ; 140$ & 4 & 2 & $1: 0.5$ & 0.67 \\
Total & 112 & 69 & $1: 0.61$ & $10.21^{1}$ \\
\hline
\end{tabular}

${ }^{1}$ Significantly different from 1:1 sex ratio at $P<0.05$.

2 Eight fishes were mutilated, their standard length was not considered in length classification.

of pooled river samples was dominated by males, with female to male ratios significantly different $\left(\chi^{2}=8.04, P<0.05\right)$ from unity (Table I). When rivers were considered separately (Table I), sex ratios were still male-biased and differed significantly from unity in Noé $\left(\chi^{2}=14.06\right)$ and Eholie $\left(\chi^{2}=6.12\right)$. The same inclination was obtained when the sex ratio was observed seasonally $\left(\chi^{2}=8.04, P<0.05\right.$, for the pooled seasons). Significant deviation from the 1:1 sex ratio was obtained during the long rainy season (LRS) and short dry season (SDS) with $\chi^{2}$ values, respectively, equal to 8.25 and 6.12 at $P<0.05$. Sex ratios were not different from unity in all size classes (Table I), except the size class $70-80 \mathrm{~cm}$ SL where the number of males was significantly higher $\left(\chi^{2}=4, P<0.05\right)$.

\section{> GONADOSOMATIC INDEX (GSI) AND SPAWNING SEASON}

The cycle of gonad maturation was followed throughout the period of investigation by defining five stages of maturation (stages I, II, III, IV and V) based on color, shape and size of the gonads (Table II).

Assessment of the main spawning period of $C$. guntheri in rivers was based on seasonal analysis of the female gonadosomatic indices (GSI) and percentage of mature individuals. Data from Eholié were not sufficient to perform seasonal analyses. Thus, the three other rivers were considered in these analyses. 
Table II

Macroscopic description of Chromidotilapia guntheri ovaries and testes at five stages of development; stages adopted by Hardie et al. (2007) and modified in this study.

Tableau II

Description macroscopique des ovaires et des testicules de Chromidotilapia guntheri aux cinq stades de développement gonadique, adoptée par Hardie et al. (2007) et modifiée dans cette étude.

\begin{tabular}{ll}
\hline Stage & Macroscopic appearance \\
\hline I. Immature & Lobes of testes and ovaries thin and transparent and not meeting each \\
& other at the ventral end of visceral cavity. Ovary and testis like a thin \\
transparent colorless thread. Oocytes are not visible to the naked eye \\
and sex cannot be discerned.
\end{tabular}

II. Mature developing Ovary and testis like a slightly swollen semitransparent gray-red thread. Lobes of testes and ovaries close to meeting each other at the ventral end of visceral cavity. Testes white in color with vermicular appearance. Oocytes distinct, and variable in size, some white, some yellow.

III. Ripening

Lobes of testes and ovaries meeting each other at the ventral end of visceral cavity. Testes white in color with vermicular appearance. All oocytes yellow-orange in color but small in size.

IV. Ripe Body wall very distended with testes and ovaries filling the visceral cavity. Testes are white in color. Oocytes are uniform in size and yelloworange in color. Oocytes and sperm are easily released even after light pressure.

V. Spent

Lobes of testes have slack appearance. Testes may have gray color. An obvious decrease in the amount of ripe oocytes present in visceral cavity. Remaining oocytes may be disfigured and more pale in color than viable oocytes.

The peaks of the GSI were observed during the short dry season (SDS) in the three rivers (Figures 2a, 2b and 2c). High proportions of mature individuals occurred during the long rainy season (LRS), short rainy season (SRS) and short dry season (SDS), respectively, in Ehania, Noé and Soumié. From these observations, nonseasonal breeding becomes apparent and the fish appears to spawn several times a year. Nevertheless, spawning activity seems relatively intense during the short dry season (SDS).

\section{> LENGTH AT FIRST MATURITY}

The length at first maturity (L50) was estimated for both sexes in each river as the standard length at which $50 \%$ of the fish were mature. Only six females were collected in Eholié river, so the L50 was estimated as the shortest mature female (logistic regression could not be performed). Thus, the smallest female found in this river was $102.5 \mathrm{~mm} \mathrm{SL}$ and weighed $38.76 \mathrm{~g}$. Logistic regression models estimating $L 50$ provided a good fit to the data from Ehania, Noé and Soumié (Levenberg Marquardt and Quasi-Newton goodness-of-fit tests; $P<0.001$ ). Table III shows the functional equations and fitted parameters. The male L50 ranged from $69.79 \mathrm{~mm}$ SL (Eholié) to $107.12 \mathrm{~mm}$ SL (Soumié). In the female population, L50 ranged from $94.12 \mathrm{~mm}$ SL (Soumié) to $107.45 \mathrm{~mm} \mathrm{SL}$ (Noé). For pooled data of all rivers, the length at which $50 \%$ of males reached maturity was $85.53 \mathrm{~mm}$ SL, while $50 \%$ of females reached sexual maturity at $100.13 \mathrm{~mm}$ SL. The smallest male found with ripe gonads measured $66.5 \mathrm{~mm}$ SL (caught in Noé) and weighed $11.5 \mathrm{~g}$, while the smallest female captured in breeding condition reached $61.26 \mathrm{~mm} \mathrm{SL}$ (found in Ehania) and weighed $10.24 \mathrm{~g}$. No significant differences were found between male and female maturity length in each river or between rivers $\left(\chi^{2}\right.$ test with $\left.P>0.05\right)$. For the overall population, Figure 3 illustrates the curves generated by the model, for males (Figure 3a) and females (Figure 3b). Sizes at maturity were not 

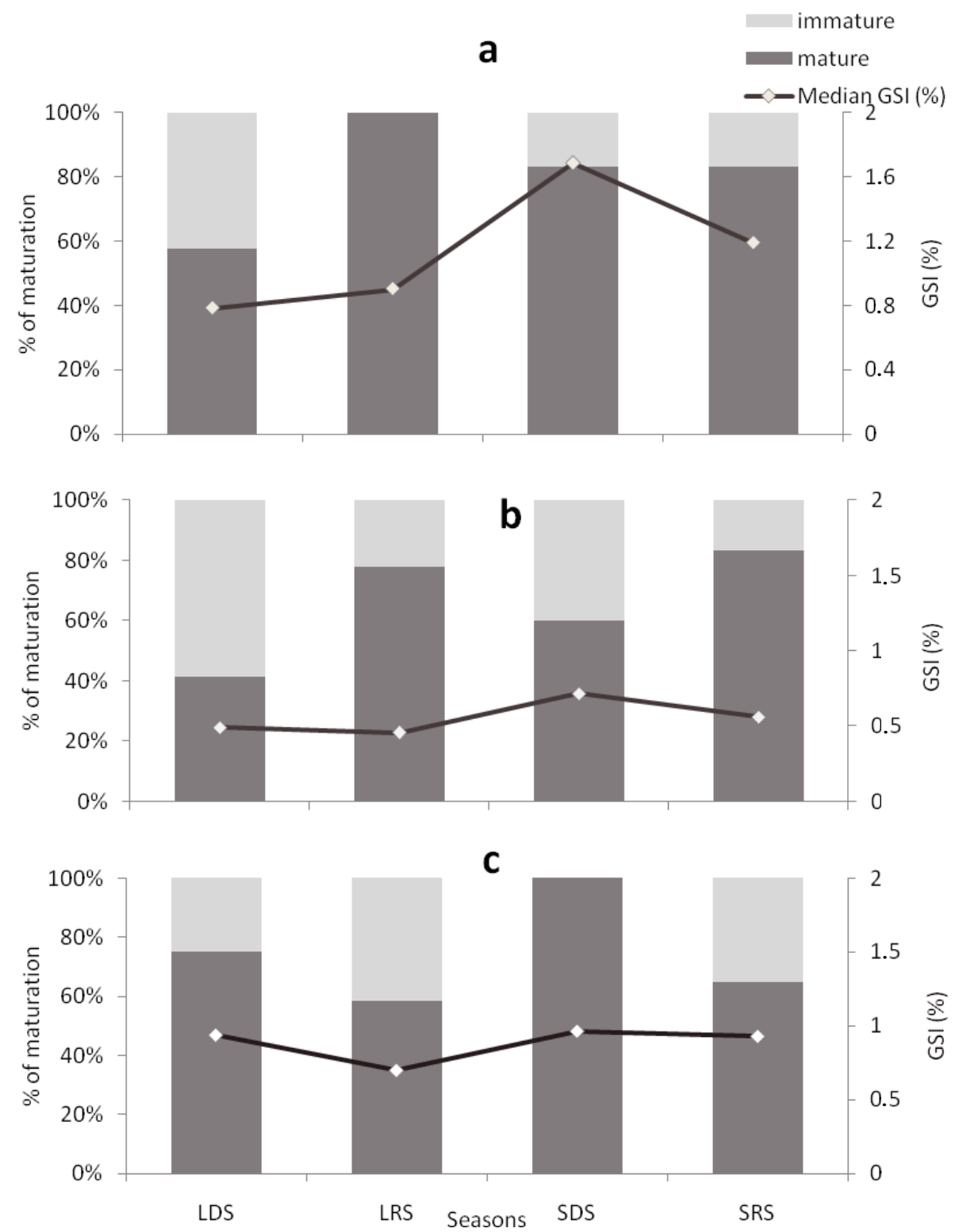

\section{Figure 2}

Seasonal percentage of mature and immature with seasonal variation in females' gonadosomatic index of C. guntheri from Ehania (a), Noé (b) and Soumié (c), three coastal rivers of Côte d'lvoire. LDS: long dry season, LRS: long rainy season, SDS: short dry season, SRS: short rainy season, GSI: gonadosomatic index.

Figure 2

Proportions des individus matures et immatures avec les variations saisonnières du rapport gonadosomatique (IGS) des femelles de Chromidotilapia guntheri des rivières Ehania (a), Noé (b) et Soumié (c), trois rivières côtières de la Côte d'Ivoire. LDS : grande saison sèche, LRS : grande saison des pluies, SDS : petite saison sèche, SRS : petite saison des pluies.

significantly different $\left(\chi^{2}=1.15\right.$, df $\left.=1, P<0.05\right)$ between males and females and are given by the following equations:

For males $(\mathrm{R}=0.97$; variance $=93.75$; standard error $=2.47 ; \mathrm{t}=34.69 ; P<0.001)$ :

$$
\mathrm{p}=1 /\left[1+\mathrm{e}^{-0.0696(\mathrm{SL}-85.53)}\right]
$$




\section{Table III}

Logistic function parameter estimate, functional equations and fitting efficiency parameters for males and females of C. guntheri sampled in four coastal rivers of Côte d'lvoire. $\mathrm{p}=$ mature individual proportion, $\mathrm{SL}=$ standard length, $\mathrm{R}=$ correlation coefficient, $\mathrm{L} 50=$ size at first maturity, $P=$ significance level of $L 50$ estimate.

\section{Tableau III}

Estimation des paramètres de la fonction logistique, des équations fonctionnelles et des paramètres de l'efficacité de l'ajustement pour les mâles et les femelles de C. guntheri collectés dans quatre rivières côtières de Côte d'Ivoire. $\mathrm{p}=$ proportion des individus matures, $\mathrm{SL}=$ longueur standard, $\mathrm{R}=$ coefficient de corrélation, $L 50$ = taille de première maturité, $P$ = niveau de significativité de l'estimation de L50.

\begin{tabular}{|c|c|c|c|}
\hline & Fitting results & Males & Females \\
\hline \multicolumn{4}{|l|}{ Soumié } \\
\hline & L50 & 107.12 & 94.12 \\
\hline & $\mathrm{R}$ & 0.91 & 0.84 \\
\hline & Variance & 81.9 & 70.22 \\
\hline & Functional equation & $\mathrm{p}==1 /\left[1+\mathrm{e}^{-0.279(\mathrm{SL}-107.9)}\right]$ & $\mathrm{p}=1 /\left[1+\mathrm{e}^{-0.067(\mathrm{SL}-94.12)}\right]$ \\
\hline & Standard error & 3.75 & 5.42 \\
\hline & $\mathrm{t}$ & 28.54 & 17.35 \\
\hline & $P$ & 0.00001 & 0.00001 \\
\hline \multicolumn{4}{|l|}{ Eholié } \\
\hline & L50 & 69.79 & \\
\hline & $\mathrm{R}$ & 0.78 & \\
\hline & Variance & 61.26 & _- \\
\hline & Functional equation & $\mathrm{p}=1 /\left[1+\mathrm{e}^{-0.082(\mathrm{SL}-69.79)}\right]$ & \\
\hline & Standard error & 6.5 & \\
\hline & $\mathrm{t}$ & 10.73 & \\
\hline & $P$ & 0.0004 & \\
\hline \multicolumn{4}{|l|}{ Ehania } \\
\hline & L50 & 77.28 & 99.35 \\
\hline & $\mathrm{R}$ & 0.89 & 0.83 \\
\hline & Variance & 78.5 & 68.8 \\
\hline & Functional equation & $\mathrm{p}=1 /\left[1+\mathrm{e}^{-0.109(\mathrm{SL}-77.28)}\right]$ & $\mathrm{p}=1 /\left[1+\mathrm{e}^{-0.086(\text { SL-99.35) }}\right]$ \\
\hline & Standard error & 5.19 & 6.33 \\
\hline & $\mathrm{t}$ & 14.88 & 15.71 \\
\hline & $P$ & 0.00001 & 0.00001 \\
\hline \multicolumn{4}{|l|}{ Noé } \\
\hline & L50 & 89.06 & 107.45 \\
\hline & $\mathrm{R}$ & 95.37 & 0.97 \\
\hline & Variance & 90.96 & 93.32 \\
\hline & Functional equation & $\mathrm{p}=1 /\left[1+\mathrm{e}^{-0.093(\mathrm{SL}-89.06)}\right]$ & $p=1 /\left[1+\mathrm{e}^{-0.086(\mathrm{SL}-107.46)}\right]$ \\
\hline & Standard error & 2.70 & 2.49 \\
\hline & $\mathrm{t}$ & 32.92 & 43.17 \\
\hline & $P$ & 0.00001 & 0.00001 \\
\hline
\end{tabular}

For females $(\mathrm{R}=0.93$; variance $=86.19$; standard error $=3.56 ; \mathrm{t}=28.10 ; P<0.001)$ :

$$
\mathrm{p}=1 /\left[1+\mathrm{e}^{-0.096(\mathrm{SL}-100.13)}\right] \text {. }
$$

\section{$>$ FECUNDITY}

Variations in Chromidotilapia guntheri fecundity within rivers and between rivers were assessed through the Kruskall-Wallis test (Table IV). Median values of absolute fecundity were 

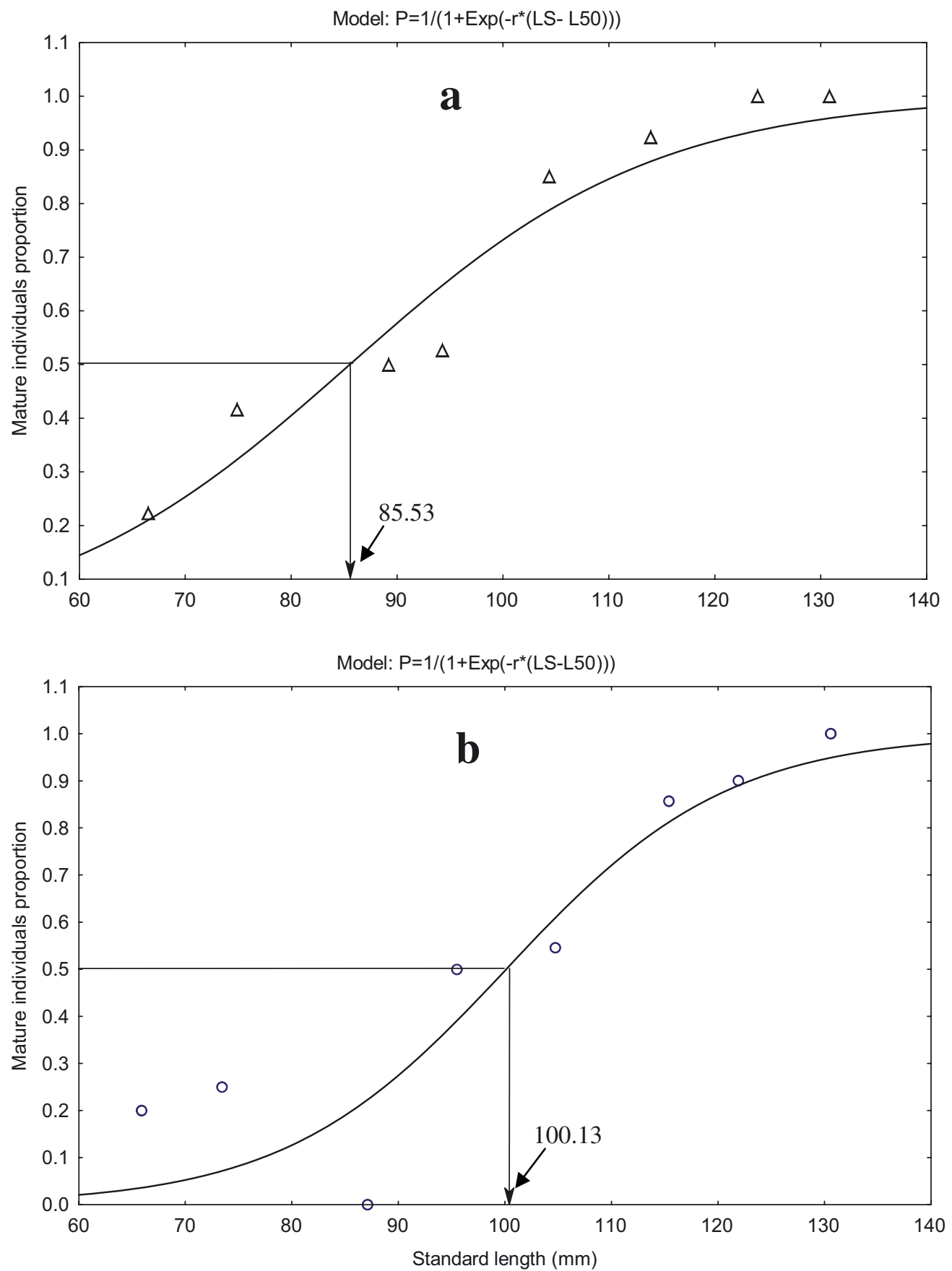

\section{Figure 3}

Length at first maturity of $\mathrm{C}$. guntheri obtained by determining the average length at which $50 \%$ of males (a) and females (b) reach maturity.

\section{Figure 3}

Tailles de première maturité sexuelle de $C$. guntheri obtenues en déterminant la taille moyenne à laquelle 50 \% des mâles (a) et des femelles (b) atteignent la maturité. 


\section{Table IV}

Median values and ranges of fecundity (absolute and relative) and oocyte diameter of Chromidotilapia guntheri females caught in four coastal rivers of Côte d'lvoire. $n=$ number of ovaries examined.

Tableau IV

Valeurs médianes et valeurs extrêmes de la fécondité (absolue et relative) ainsi que les diamètres ovocytaires des femelles de Chromidotilapia guntheri capturées dans quatre rivières côtières de la Côte d'Ivoire. $n=$ nombre d'ovaires examinés.

\begin{tabular}{lcccccc}
\hline Rivers (n) & \multicolumn{2}{c}{ Absolute fecundity } & \multicolumn{2}{c}{ Relative fecundity } & \multicolumn{2}{c}{ Oocyte diameter } \\
& Median & Min - max & Median & Min - max & Median & Min - max \\
\hline Soumié (15) & 270 & $100-467$ & 4969 & $3264-9135$ & 1.2 & $0.65-2.2$ \\
Eholié (6) & 237 & $120-334$ & 4256 & $3096-5747$ & 1.15 & $0.78-1.45$ \\
Ehania (18) & 246 & $70-470$ & 4612 & $3066-7592$ & 1.43 & $0.77-2.1$ \\
Noé (8) & 250 & $114-430$ & 4443 & $3300-5866$ & 1.14 & $0.8-1.38$ \\
\hline
\end{tabular}

237, 246, 250 and 270 eggs, respectively, in Eholié, Ehania, Noé and Soumié. Extreme values were 70 and 470 eggs, both found in Ehania. Relative fecundity calculated per river was 4256, 4443, 4612 and 4969 eggs per kilogram of fish, respectively, in Eholié, Noé, Ehania, and Soumié, with extreme values being 3066 and 9135 eggs. Fecundity (absolute and relative) values did not differ between rivers (Kruskall-Wallis, $P>0.05$ ).

The relationships between absolute fecundity and standard length, eviscerated weight (We) and oocyte diameter were evaluated in each river (Table V).

Except for Eholie river, there was a significant increase in fecundity with somatic weight (eviscerated weight) in the other rivers $(\mathrm{R}>0.80, P<0.01)$. Differences in eviscerated weight accounted for $57.39 \%, 74.7 \%, 78.5 \%$ and $88.2 \%$ of the variation in absolute fecundity, respectively, in Eholié, Ehania, Soumié and Noé.

A significant positive relationship existed between standard length and absolute fecundity $(\mathrm{R}>0.80 ; P<0.01)$, with the exception of Eholié $(\mathrm{R}=0.72 ; P=0.2)$, with $52.33 \%, 64.9 \%$, $65.42 \%$ and $74 \%$ of fecundity variation being explained by changes in standard length, respectively, in Eholié, Ehania, Noé and Soumié.

There was no significant correlation between fecundity and oocyte diameter $(R<0.7$, $P>0.01)$. Changes in egg diameters did not influence variations in fecundity.

These relationships were accessed for all rivers (Figure 4). There was a high and significant correlation between absolute fecundity and both standard length (Figure 4a) and somatic weight (Figure 4b) $(\mathrm{R}=0.81 ; P<0.001$ and $\mathrm{R}=0.86 ; P<0.001$ respectively). These two parameters influenced the variation in fecundity by $65.62 \%$ and $74 \%$. There was no significant relationship between oocyte diameter and fecundity $(\mathrm{R}<0.7 ; P>0.05)$, thus reflecting a random relationship between both variables (Figure 4c).

Oocyte diameters (Table IV) ranged from $0.65 \mathrm{~mm}$ to $2.2 \mathrm{~mm}$ (both from Soumié river). Median values per river were $1.14 \mathrm{~mm}, 1.15 \mathrm{~mm}, 1.2 \mathrm{~mm}$ and $1.43 \mathrm{~mm}$, respectively, in ovaries from Noé, Eholié, Soumié and Ehania. These values were not significantly different (Kruskal-Wallis test, $P>0.05$ ).

Oocyte diameters were then plotted against seasons (Figure 5). Although no significant differences were found between seasonal egg diameters (Kruskal-Wallis test, $P>0.05$ ), the long dry season (LDS) and the short rainy season (SRS) showed the relatively smallest and highest values of OD, respectively.

\section{DISCUSSION}

Among the populations of $C$. guntheri studied, the males were predominant within rivers, seasons and length classes. This deviation from the 1:1 sex ratio and the predominance of males might result from either physiological differences or mechanisms which render males more prone to capture or less prone to natural mortality than females (i.e. male aggressive reproductive behavior, mouth breeding). The sex ratio varies considerably among fish species. 


\section{Table $V$}

Functional equations for the relationships between absolute fecundity (F) and standard length (SL), somatic weight (We) and oocyte diameter (OD) of C. guntheri from four coastal rivers of Côte d'lvoire. $\mathrm{SE}=$ standard error, $\mathrm{R}=$ correlation coefficient, $P=$ significance level of $\mathrm{b}$ estimate.

\section{Tableau V}

Équations fonctionnelles des relations entre la fécondité absolue (F) et la longueur standard (SL), le poids somatique $(\mathrm{We})$ ou le diamètre ovocytaire $(\mathrm{OD})$ de $C$. guntheri de quatre rivières côtières de Côte d'Ivoire. SE = erreur standard, $\mathrm{R}=$ coefficient de corrélation, $P=$ niveau de significativité de l'estimation de b.

\begin{tabular}{|c|c|c|c|c|c|c|}
\hline Rivers & $\begin{array}{l}\text { Relationships } \\
\text { Fecundity vs.: }\end{array}$ & $\begin{array}{l}\text { Functional equation } \\
\qquad\left(F=a X^{b}\right)\end{array}$ & Variance & SE & $\mathrm{R}$ & $P$ \\
\hline \multirow[t]{3}{*}{ Soumié } & Standard length & $\mathrm{F}=0.0012 \mathrm{SL}^{2.62}$ & 74 & 0.57 & 0.86 & 0.0005 \\
\hline & Somatic weight & $\mathrm{F}=4.34 \mathrm{We}^{1.04}$ & 78.5 & 0.2 & 0.89 & 0.0001 \\
\hline & Egg diameter & $\mathrm{F}=284.4 \mathrm{OD}^{-0.039}$ & 0.1 & 0.26 & 0.04 & 0.89 \\
\hline \multirow[t]{3}{*}{ Eholié } & Standard length & $F=0.0012 S L^{2.59}$ & 52.33 & 1.7 & 0.72 & 0.2 \\
\hline & Somatic weight & $\mathrm{F}=3.85 \mathrm{We}^{1.03}$ & 57.39 & 0.49 & 0.76 & 0.1 \\
\hline & Egg diameter & $F=233.27 O^{-0.09}$ & 0.4 & 0.82 & 0.06 & 0.92 \\
\hline \multirow[t]{3}{*}{ Ehania } & Standard length & $F=0.0017 S L^{2.52}$ & 64.9 & 0.67 & 0.81 & 0.0017 \\
\hline & Somatic weight & $\mathrm{F}=3.22 \mathrm{We}^{1.07}$ & 74.7 & 0.21 & 0.86 & 0.00001 \\
\hline & Egg diameter & $\mathrm{F}=227.910 D^{0.26}$ & 3.3 & 0.35 & 0.18 & 0.47 \\
\hline \multirow[t]{3}{*}{ Noé } & Standard length & $F=0.0013 S L^{2.59}$ & 65.42 & 1.35 & 0.81 & 0.11 \\
\hline & Somatic weight & $\mathrm{F}=0.31 \mathrm{We}^{1.67}$ & 88.2 & 0.3 & 0.94 & 0.0015 \\
\hline & Egg diameter & $\mathrm{F}=243.5 \mathrm{OD}^{0.98}$ & 20.14 & 0.88 & 0.45 & 0.31 \\
\hline \multirow[t]{3}{*}{ Overall rivers } & Standard length & $F=0.0007 S L^{2.72}$ & 65.62 & 0.42 & 0.81 & 0.00001 \\
\hline & Somatic weight & $\mathrm{F}=2.54 \mathrm{We} \mathrm{e}^{1.15}$ & 74 & 0.13 & 0.86 & 0.00001 \\
\hline & Egg diameter & $F=255.2 O D^{0.08}$ & 0.5 & 0.44 & 0.07 & 0.66 \\
\hline
\end{tabular}

Examples of such variation in the tropical species were reported by Giamas et al. (1984), and Goulart and Verani (1992), who found higher frequency of males, whereas Rodrigues et al. (1989a) observed higher frequency of females. Rodrigues et al. (1989b) and Andrian et al. (1992) reported a sex ratio of 1:1.

The gonadosomatic index (GSI) hardly reached $2 \%$ in the present study. Low values of the GSI are typical of Cichlidae, in which this index reaches only about 5\% (Paugy et al., 2002). The smaller values of the GSI in the present study and the nonexistence of veritable peaks in the seasonal GSI and percentage of mature fish suggest that $C$. guntheri is a multiple (fractional) spawner and breeds all year round with little fluctuation in spawning intensity. Indeed, Wootton (1999) suggested a relationship between GSI values and the reproductive strategy of fishes. This author observed that higher values of the GSI predominated in the species that were total spawners, whereas the lower and intermediate values were more frequent in the fishes that were multiple spawners. Nevertheless, in spite of the lack of monthly samples to establish the picture frequently adopted to describe the fishes' reproductive period (Garutti, 1989; Goulart, 1994; Vazzoler, 1996; Hotos et al., 2000; Rutaisire and Booth, 2005; Vallisneris et al., 2006; Hardie et al., 2007; Allison et al., 2008), the higher frequency of mature specimens with a high GSI in August and September (short dry season) was evidence for more intensive spawning activities in these months.

Most of the species inhabiting the Nilo-Sudanian region exhibit a breeding strategy in relation to flood seasonality (Paugy, 2002). Thus, the relatively intensive reproductive activity shown by $C$. guntheri in the months of August and September is imputable to the fact that this period corresponds to the flooding period in this area. Likewise, Billard and Breton (1978) suggested that temperature can play an important role in governing reproductive activity in fish 
a

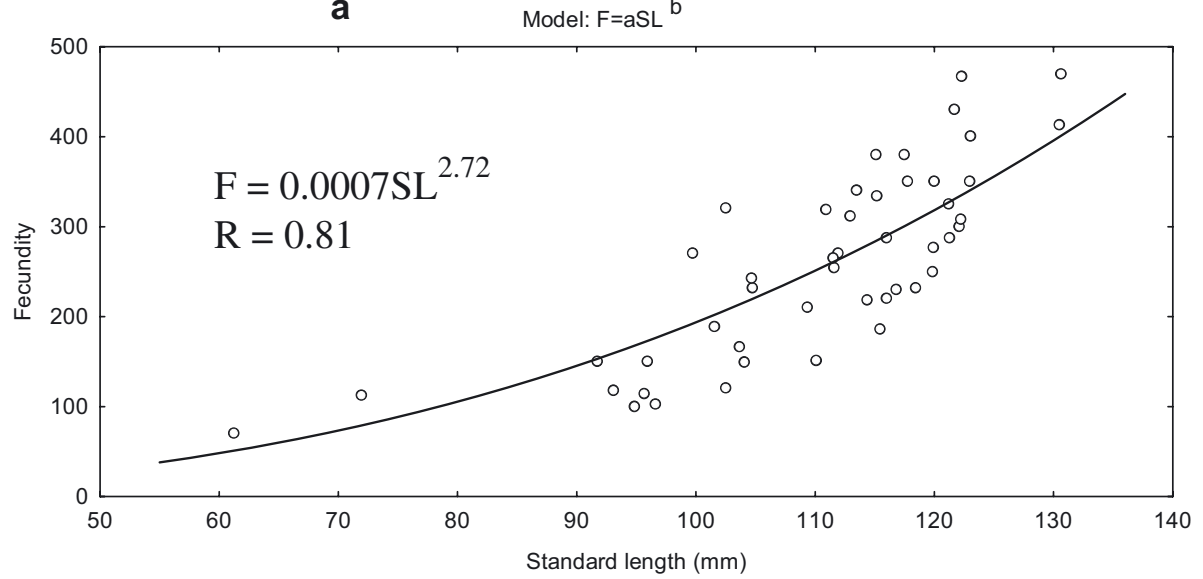

b

Model: $\mathrm{F}=\mathrm{aWe} \mathrm{e}^{\mathrm{b}}$
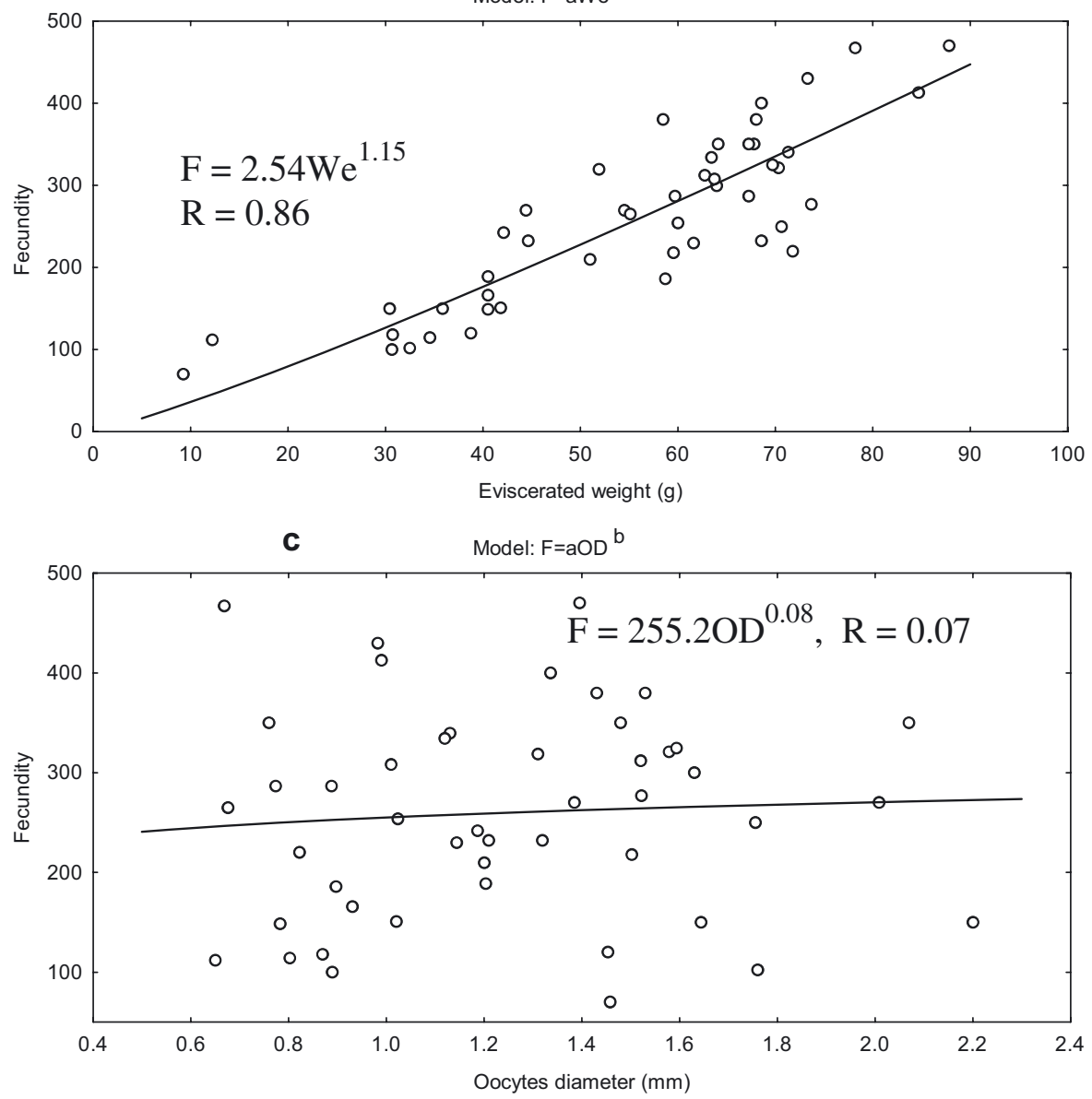

Figure 4

Scatter diagram showing relationship between fecundity (F) and standard length (SL) (a), fecundity and somatic weight (We) (b), and between fecundity and oocyte diameter (OD) (c) of C. guntheri. The curves were fitted by the calculated regressions.

Figure 4

Nuages de points montrant la relation entre la fécondité $(\mathrm{F})$ et la longueur standard (SL) (a), la fécondité et le poids éviscéré (We) (b) et entre la fécondité et le diamètre des ovocytes (OD) (c) de C. guntheri. Les courbes ont été estimées à partir des modèles de régression adoptés. 


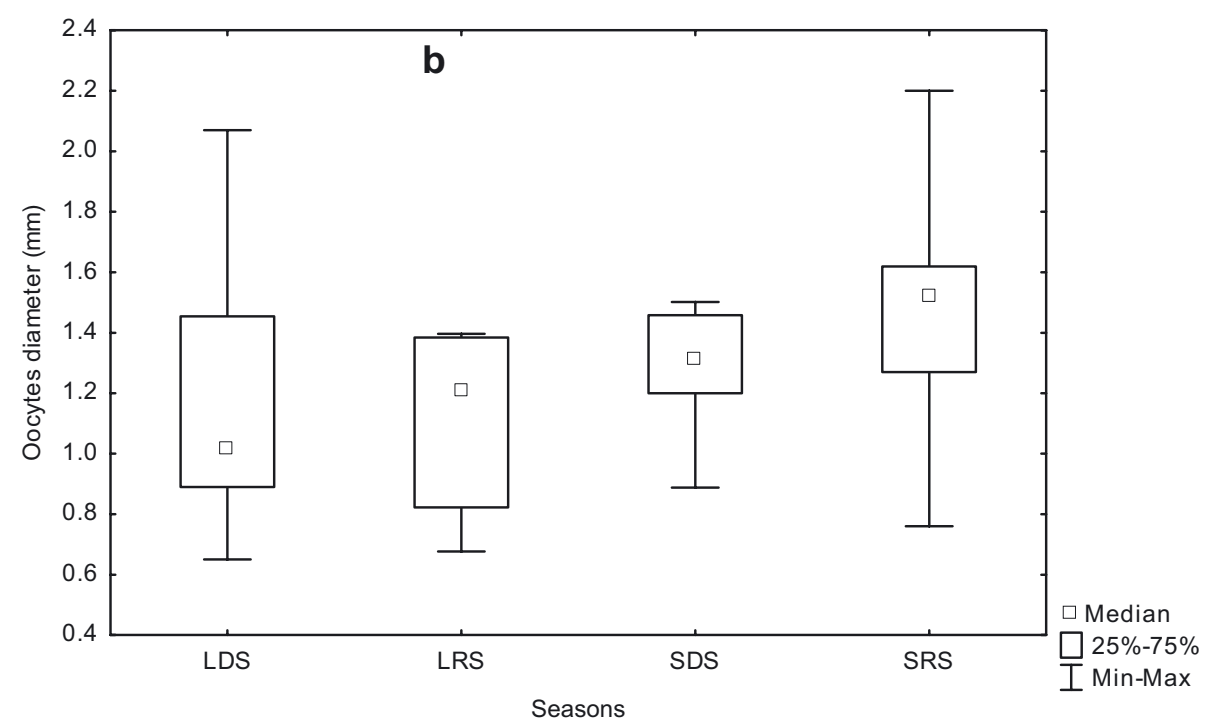

\section{Figure 5}

Seasonal variations in oocyte diameter of C. guntheri from four rivers of Côte d'Ivoire.

Figure 5

Variations saisonnières des diamètres ovocytaires de C. guntheri des quatre rivières prospectées.

populations. In the water bodies studied, the water temperature was constantly higher than $24^{\circ} \mathrm{C}$. According to Duponchelle et al. (1999), this temperature is favorable for Cichlid reproduction. That may explain the year-round spawning activity of $C$. guntheri. However, intensive reproductive activity occurs around $25^{\circ} \mathrm{C}$. The appearance of all stages of gonad development all year round also indicated that $C$. guntheri might be a partial spawner. Ikomi and Sikoki (2003) observed that it is characteristic of multiple spawners to have ovaries of all stages of development occurring at any particular time. Fractional spawning, according to Olatunde (1978), has evolved in some species as an adaptation to food supply. It also ensures the preservation of the species under unfavorable conditions (Nikolsky, 1963).

Length at first maturity (L50) of $C$. guntheri from the rivers studied is similar in both sexes, although males seem to spawn at a relatively smaller length $(85.53 \mathrm{~mm} \mathrm{SL})$ than females (100.13 mm SL). Similar size at maturity between male and female specimens was also observed in Sarotherodon leonensis in Kainji Lake (Otobo, 1978). The beginning of sexual maturation represents a critical period for animals that continue to grow after reaching maturity because, from this point on, a potential conflict is established involving the allocation of resources for survival, growth and reproduction (Wootton, 1990). Accordingly, similar length at first maturity between males and females testifies that both sexes would allocate similar quantities of resources for reproduction. Indeed, according to Albaret (1982), both parents take care of the young after hatching. The same reference reported, however, a lower female maturity length $(60 \mathrm{~mm})$ of $C$. guntheri in Côte d'Ivoire freshwaters.

The fecundity of the populations was also investigated since it is known to vary among populations, and at times, between strains of fish species (Jonsson and Jonsson, 1999). In the present study, fecundity ranges were similar in the four rivers. Indeed, median values of absolute fecundity were 237, 246, 250 and 270 eggs, respectively, in Eholié, Ehania, Noé and Soumié. Extreme values of fecundity were 70 and 470 eggs. All these values were not far from those found by Fagade (1983), who reported for C. guntheri an absolute fecundity ranging from 313 to 491 in a small lake in the Niger Delta. The fecundity of $C$. guntheri seems to be low compared with that of other Cichlids such as Sarotherodon mossambicus (660 to 1754 eggs) in Plover Cove Reservoir (Hodgkiss and Hanson 1978), and Tilapia zillii (2990 to 12334 eggs) in Lake Naivasha (Siddiqui, 1979). Like C. guntheri, all fish that exhibit low fecundity have been distinguished by Lowe-McConnell (1987) as 'small-brood-spawner'. He explained that 
their spawning strategy consists of giving parental care and producing small batches of eggs at frequent intervals most of the year. The median values of relative fecundity calculated per river were 4256, 4443, 4612 and 4969 eggs per kilogram of fish, respectively, in Eholié, Noé, Ehania, and Soumié, with extreme values being 3066 and 9135 eggs. The notable variation in individual fecundity in the current study may be due to the inclusion of fish for fecundity estimates which have already spawned at least once and gave low oocyte counts.

In the present study, the fecundity of $C$. guntheri increased in proportion to the 2.72 power of standard length (SL) and the 1.15 power of eviscerated weight (We). The b-values (coefficient of regression) obtained here are closer to those indicated by Bagenal and Braum (1978), who asserted that in many fish species, the b-value is usually about 3 when fecundity is related to length and about 1 when related to weight. According to Kartas and Quignard (1984), the b-value describes the type of allometry in fitting the increase rate of fecundity compared with length or weight. Hence, in the current study, C. guntheri fecundity increased almost proportionally to the body volume and is quite proportional to the eviscerated weight. It thus seems that somatic weight is the most stable morphometric attribute explaining the variation in C. guntheri fecundity. The plot of fecundity against oocyte diameter indicated that there was no tendency for fecundity to change with changes in oocyte size.

The wide range of egg diameters $(0.65-2.2 \mathrm{~mm})$ may be associated with the fact that C. guntheri spawns more than once. Allison et al. (2008) observed the same pattern in egg diameter of Parailia pellucida in the Niger Delta.

\section{ACKNOWLEDGEMENTS}

This study was funded by the partnership between the FEM/ONG (Fonds pour l'Environnement Mondial/Organisation Non Gouvernementale) and the CREPA-CI (Centre Régional pour l'Eau Potable et l'Assainissement à faible coût - Côte d'Ivoire) directed by Prof. T. Gnagne. We are grateful to E.N. Assemian, M.K. Konan and M.K. Kouamé (Laboratoire d'Environnement et de Biologie Aquatique, Abobo-Adjamé University, Côte d'Ivoire) for their valuable help and advice.

\section{REFERENCES}

Albaret J.J., 1982. Reproduction et fécondité des poissons d'eau douce de Côte d'Ivoire. Rev. Hydrobiol. Trop., 15, 347-371.

Allison M.E., Sikoki F.D. and Vincent-Abu I.F., 2008. Fecundity, sex ratio, maturity stages, size at first maturity, breeding and spawning, of Parailia pellucida (Boulenger, 1901) in the lower Nun River, Niger Delta, Nigeria. Caderno de Pesquisa Sér. Bio., 20, 31-47.

Andrian I.F., Barbieri G. and Júlio Jr. H.F., 1992. Aspectos da estrutura da população de Parauchenipterus galeatus Linnaeus, 1766 (Siluriformes, Auchenipteridae) da região do reservatório de Itaipu-PR. Rev. Unimar, 14, 73-87.

Bagenal T.B. and Braum E., 1978. Eggs and early life history. In: Methods for assessment of fish production in fresh waters ( $3^{\text {rd }}$ edn.), International Biological Program Handbook, 3, 101-136.

Billard R. and Breton B., 1978. Rhythms of reproduction in teleost fish. In: Thorpe J.E. (ed.), Rhythmic activities of fishes, Academic Press, London, 31-53.

Da Costa S.K., Gourène G., Tito De Morais L. and Thys van den Audenaerde D.F.E., 2000. Caractérisation des peuplements ichtyologiques de deux fleuves côtiers ouest-africains soumis à des aménagements hydro-agricoles et hydroélectriques. Vie Milieu, 50, 65-77.

Dadebo E., Ahlgren G. and Ahlgren I., 2003. Aspects of reproductive biology of Labeo horie Heckel (Pisces: Cyprinidae) in lake Chamo, Ethiopia. Afr. J. Ecol., 41, 31-38.

Daget J. and IItis A., 1965. Poissons de Côte d'Ivoire (eaux douces et saumâtres) - Dakar, Édition IFAN (Institut Français de l'Afrique Noire), 74.

Dobzhansky T., 1956. What is an adaptative trait? Amer. Nat., 90, 337-347. 
Duponchelle F., Cecchi P., Corbin D., Nunez J. and Legendre M., 1999. Spawning season variations of female Nile tilapia, Oreochromis niloticus, from man-made lakes of Côte d'Ivoire. Env. Biol. Fish., 56, 375-387.

Fagade S.O., 1983. The biology of Chromidotilapia guntheri from a small lake. Arch. Hydrobiol., 97, 60-72.

Garutti V., 1989. Contribuição ao conhecimento reprodutivo de Astyanax bimaculatus (Ostariophysi, Characidae), em cursos de água da bacia do rio Paraná. Rev. Brasil. Biol., 49, 489-495.

Giamas M.T.D., Mota A., Rodrigues J.D. and Mandelli Jr J., 1984. Dinâmica da nutrição da manjuba, Anchoviella lepidentosole (Fowler, 1911) (Osteichthyes, Engraulidae), do rio Ribeira do Iguape, Estado de São Paulo, Brasil. B. Inst. Pesca, 11, 107-113.

Goulart E., 1994. Estrutura da população, idade, crescimento, reprodução e alimentação de Auchenipterus nuchalis (Spix, 1826) (Osteichthyes, Auchenipteridae) do reservatório de Itaipu-PR. Ph.D. Thesis, Universidade Federal de São Carlos, São Paulo.

Goulart E. and Verani J.R., 1992. Proporção sexual, relação peso-comprimento e fator de condição do cascudo Hypostomus commersonii Valenciennes, 1840 (Osteichthyes-Loricariidae) da represa Capivari-Cacheira, Paraná, Brasil. Rev. Unimar, 14, 19-33.

Gourène G., Teugels G.G., Hugueny B. and Thys van den Audenaerde D.F.E., 1999. Évaluation et conservation de la diversité ichtyologique d'un bassin ouest-africain après la construction d'un barrage. Cybium, 23, 147-160.

Hardie S.A., White R.W.G. and Barmuta L.A., 2007. Reproductive biology of the threatened golden galaxias Galaxias auratus (Johnston) and the influence of lake hydrology. J. Fish Biol., 71, 18201840.

Hodgkiss I.J. and Hanson S.H.M., 1978. Reproductive biology of Sarotherodon mossambicus (Cichlidae) in Plover Cove Reservoir, Hong Kong. Env. Biol. Fishes, 3, 293-296.

Hotos G.N., Avramidou D. and Ondrias I., 2000. Reproduction biology of Liza aurata (Risso, 1810), (Pisces Mugilidae) in the lagoon of Klisova (Messolonghi, W. Greece). Fish. Research, 47, 57-67.

Ikomi R.B. and Sikoki F.D., 2003. Studies on the Biology of the African Lonfin Tetra, Brycinus Iongipinnis (Gunther, 1964) in the Jamieson River (Niger Delta, Nigeria). Acta Ichthyol. Piscat., 33, 17-36.

Jonsson N. and Jonsson B., 1999. Trade-off between egg mass and egg number in brown trout. J. Fish Biol., 55, 767-783.

Kartas F. and Quignard J.P., 1984. La fécondité des poissons téléostéens, Masson, Collection biologie des milieux marins, 5, Paris.

Konan F.K., Leprieur F., Ouattara A., Brosse S., Grenouillet G., Gourène G., Winterton P. and Lek S., 2006. Spatio-temporal patterns of fish assemblages in coastal West African rivers: a self-organizing map approach. Aquat. Living Resour., 19, 361-370.

Lévêque C., Paugy D. and Teugels G.G., 1991. Annotated check-list of the freshwater fishes of the Nilo-sudan river basins, in Africa. Rev. Hydrobiol. Trop., 24, 131-154.

Lowe-McConnell R.H., 1987. Ecological studies in tropical fish communities, University Press, Cambridge.

Merron G.S., Holden K.K. and Bruton M.N., 1990. The reproductive biology and early development of the African pike, Hepsetus odoe, in the Okavango Delta, Botswana. Env. Biol. Fishes, 28, 215-235.

Nikolsky G.V., 1963. The Ecology of Fishes, London Academic Press.

Olatunde A.A., 1978. Sex, reproductive cycle and variations in the fecundity of the family Schilbeidae (Osteichthyes: Siluriformes) in Lake Kainji, Nigeria. Hydrobiologia, 57, 125-142.

Otobo F.O., 1978. The reproductive biology of Pellonula afzeliusi (Johnels) and Sierathrissa leonensis (Thys Audenaerde) in Lake Kainji Nigeria. Hydrobiologia, 61, 99-112.

Paugy D., 2002. Reproductive strategies of fishes in a tropical temporary stream of the Upper Senegal basin: Baoulé River in Mali. Aquat. Living Resour., 15, 25-35.

Paugy D., Traoré K. and Diouf P.S., 1994. Faune ichtyologique des eaux douces d'Afrique de l'Ouest. In: Teugels G.G., Guégan J.F. et Albaret J.J. (eds.), Diversité des poissons des eaux douces et saumâtres d'Afrique, Ann. Mus. R. Afr. Centr., 177, 35-66.

Paugy D., Lévêque C. and Teugels G.G., 2003. Poissons d'eaux douces et saumâtres de l'Afrique de I'Ouest, Édition complète, Tomes I \& II, Édition IRD, MNHN, MRAC. 
Peixer J., Mateus L.A.F. and Resende E.K., 2006. First gonadal maturation of Pinirampus pirinampu (Siluriformes: Pimelodidae) in the Pantanal, Mato Grosso do Sul State, Brazil. Braz. J. Biol., 66, 317-323.

Rodrigues A.M., Rodrigues J.D., Campos E.C. and Ferreira A.E., 1989a. Aspectos da estrutura populacional e época de reprodução do tambiú Astyanax bimaculatus (Characiformes, Characidae) na represa de Bariri, rio Tietê, estado de São Paulo, Brasil. B. Inst. Pesca, 16, 97-110.

Rodrigues A.M., Rodrigues J.D., Ferreira A.E. and Campos E.C., 1989b. Aspectos da estrutura populacional do saguiru Curimata cf. elegans (Steindachner, 1875) (Osteichthyes, Curimatidae) e época de sua reprodução na represa de Bariri, rio Tietê, estado de São Paulo, Brasil. B. Inst. Pesca, 16, 57-65.

Rutaisire J. and Booth A.J., 2005. Reproductive biology of ningu, Labeo victorianus (Pisces: Cyprinidae), in the Kagera and Sio Rivers, Uganda. Env. Biol. Fishes, 73, 153-162.

Sadeghi M.S., Kaymaram F., Jamili S., Fatemi M.R. and Mortazavi M.S., 2009. Patterns of reproduction and spawning of the Scomberomorus commerson in the coastal waters of Iran. J. Fish. Aquat. Sci. , 4, 32-40.

Siddiqui A.Q., 1979. Reproductive biology of Tilapia zillii (Gervais) in Lake Naivasha, Kenya. Env. Biol. Fishes, 4, 257-262.

StatSoft Inc., 2005. STATISTICA for Windows (Data Analysis Software System), Version 7.1, Tulsa OK: StatSoft.

Tarkan A.S., 2006. Reproductive ecology of two cyprinid fishes in an oligotrophic lake near the southern limits of their distribution range. Ecol. Freshwater Fishes, 15, 131-138.

Teugels G.G., Lévêque C., Paugy D. and Traoré K., 1988. État des connaissances sur la faune ichtyologique des bassins côtiers de Côte d'Ivoire et de l'ouest du Ghana. Rev. Hydrobiol. Trop., 21, 221-237.

Vallisneris M., Scapolatempo M. and Tommasini S., 2006. Reproductive biology of Merlangius merlangus (L.) (Osteichthyes, Gadidae) in the northern Adriatic Sea. Acta Adriat., 47, 159-165.

Vazzoler A.E.A. de M., 1996. Biologia da reprodução de peixes teleósteos: teoria e prática, EDUEM, Maringá, Sao Paulo, SBI.

Vivien J., 1991. Faune du Cameroun - Guide des mammifères et des poissons, GICAM.

Wootton R.J., 1990. Ecology of Teleost Fishes, Chapman \& Hall, London.

Wootton R.J., 1999. Ecology of teleost fishes, Kluwer, Academic Publishers, Dordrecht. 